\title{
ERRATA
}

\section{Intra- and Intergeneric Similarities of Agrobacterium Ribosomal Ribonucleic Acid Cistrons}

\author{
J. DE SMEDT AND J. DE LEY \\ Laboratory of Microbiology and Microbial Genetics, Faculty of Sciences, State University, \\ B-9000 Ghent, Belgium
}

Volume 27, no. 3, p. 226, Table 1-Continued: Footnote $b$ should read "The G+C values for 14 Arthrobacter strains were taken from Skyring et al. (64). All others were determined in our laboratory on previous occasions by thermal denaturation."

\section{Serratia proteamaculans (Paine and Stansfield) comb. nov., a Senior Subjective Synonym of Serratia liquefaciens (Grimes and Hennerty) Bascomb et al.}

PATRICK A. GRIMONT, FRANCINE GRIMONT, AND MORTIMER P. STARR

Department of Bacteriology, University of California, Davis, California 95616

Volume 28 , no. 4 , p. 509 , column 1: The printer inadvertently dropped the last line of the first paragraph. The sentence should read ". . . built and followed quite different taxonomic systems." 